\title{
Pengembangan Modul Sosioteknologi Informatika Berbasis CDIO
}

\author{
Akhimullah Akmal Fattah, Aji Prasetya Wibawa, Muhammad Iqbal Akbar, \\ Roni Herdianto
}

Universitas Negeri Malang Jl. Semarang No.5 Sumbersari Kec. Lowokwaru, Kota Malang 65145, Indonesia

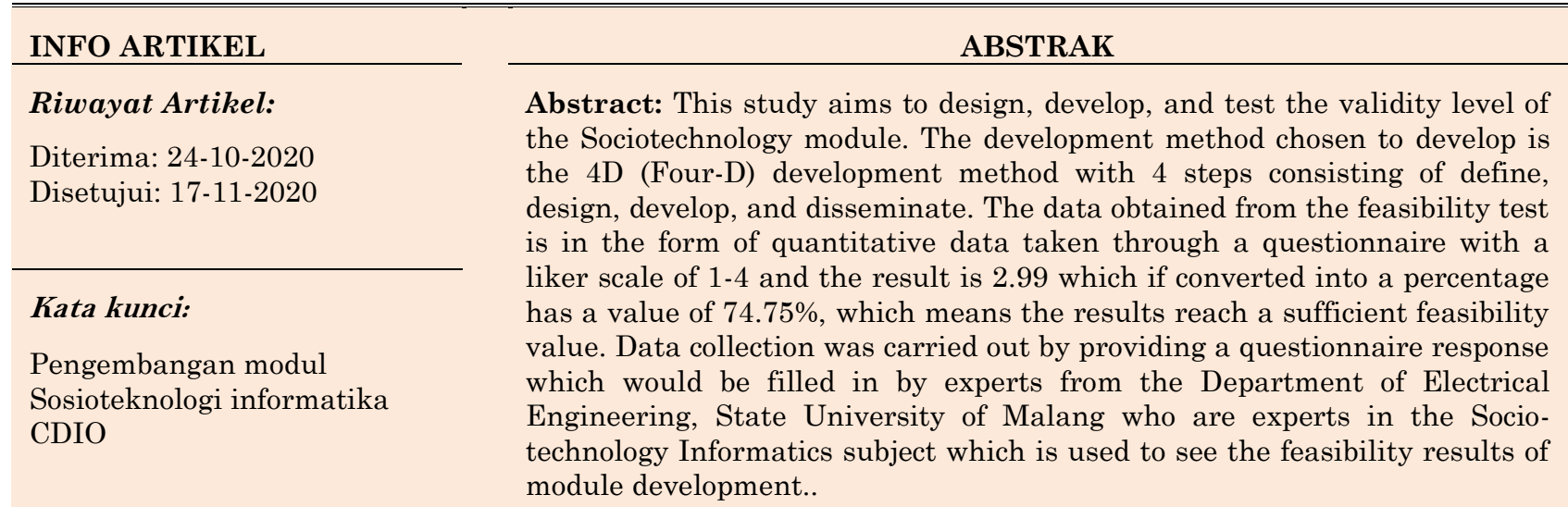

\begin{abstract}
Abstrak: Penelitian ini bertujuan untuk merancang, mengembangkan, dan menguji tingkat kevalidan modul Sosioteknologi. Metode pengembangan yang dipilih untuk mengembangkan adalah metode pengembangan 4D (Four-D) dengan 4 tahapan langkah yang terdiri dari define (pendefinisian), design (perancangan), develop (pengembangan), dan disseminate (penyebaran). Data yang diperoleh dari uji kelayakan berupa data kuantitatif yang diambil melalui media angket dengan skala liker 1-4 dan diperoleh hasil 2,99 yang jika dikonversikan ke dalam persentase bernilai 74,75\% yang berarti hasil mencapai nilai kelayakan yang cukup. Pengumpulan data dilakukan dengan cara memberikan angket tanggapan yang akan diisi oleh para ahli dari Jurusan elektro Universitas Negeri Malang yang ahli dalam bidang mata kuliah Sosioteknologi Informatika yang digunakan untuk melihat hasil kelayakan dari pengembangan modul.
\end{abstract}

\author{
Alamat Korespondensi: \\ Aji Prasetya Wibawa \\ Jurusan Teknik Elektro \\ Fakultas Teknik \\ Universitas Negeri Malang \\ Jl. Semarang No.5 Sumbersari Kec. Lowokwaru, Kota Malang 65145, Indonesia \\ E-mail: aji.prasetya.ft@um.ac.id
}

\section{PENDAHULUAN}

Pada Program Studi S1 teknik Informatika yang termasuk di Fakultas Teknik Universitas Negeri Malang terdapat mata kuliah Sosioteknologi Informatika yang mengajarkan mahasiswa untuk melihat pengaruh perkembangan dan juga pengaruh perubahan teknologi Informasi dalam kehidupan sosial. Dengan pengaruh tersebut membuat manusia akan berinteraksi terhadap teknologi Informasi secara sadar maupun tidak (Nasrullah, 2018; Utami et al., 2016). 
Sampai saat ini, kegiatan perkuliahan untuk mata kuliah Sosioteknologi Informatika masih menggunakan slide presentasi sebagai satu-satunya bahan ajar untuk menyampaikan materi perkuliahan. Hal tersebut menyebabkan beberapa materi yang disajikan sulit dipahami dan dimengerti karena bersifat penjelasan-penjelasan yang terlalu Panjang (Anwar, 2010; Cahyono, 2014). Oleh karena itu, agar mudah dipahami dan mudah dimengerti maka perlu ada bahan ajar lain yang mendukung perkuliahan mata kuliah Sosioteknologi Informatika. Salah satu produk unggulan yang sering dimanfaatkan dalam kegiatan pembelajaran yaitu modul (Daryanto, 2013; Harmawati et al., 2017).

Modul adalah salah satu bahan ajar yang cara penyusunannya harus sistematis dan juga menarik yang berisi materi metode dan evaluasi agar dapat dijadikan sebagai bahan ajar mandiri untuk mencapai indikator yang akan dicapai (Anggoro, 2015; Prastowo, 2011). Modul yang merupakan produk terobosan teknologi informasi yang bisa dijadikan bahan ajar peserta didik untuk memudahkan mempelajari suatu materi pelajaran yang akan diajarkan oleh dosen. Selain itu, penggunaan modul untuk kegiatan belajar mengajar mampu memicu peserta didik maupun dosen dalam menumbuhkan minat dan semangat pembelajaran (Harmawati et al., 2017; Lubis et al., 2014; Sugiyono, 2016).

Maka pada penelitian ini, akan dibuat modul pembelajaran untuk mata kuliah Sosioteknologi Informatika berbasis CDIO. Model pembelajaran CDIO itu sendiri adalah metode pembelajaran yang mengajarkan peserta didik menyelesaikan suatu problem yang berkaitan langsung dalam kehidupan nyata (Dwiyanto, 2018; Setyosari, 2010). Tujuan dibuat modul dengan berbasis CDIO adalah untuk meningkatkan kemampuan memahami dan memecahkan suatu permasalahan bagi peserta didik dan sebagai media bahan ajar yang dapat membantu dosen dalam pelaksanaan perkuliahan (Bachtiar, 2018; Zhulin, 2017).

\section{METODE}

Pada penelitian dan pengembangan ini peneliti menggunakan model 4D (Four-D) seperti yang tercantum pada Gambar 1. Model 4D dipilih karena setiap langkah dan tahap pengembangannya sangat cocok untuk digunakan untuk mengembangkan dan menghasilkan sebuah produk berupa modul pada mata kuliah Sosioteknologi Informatika. Model 4D mempunyai 4 tahapan langkah utama yaitu mendefinisikan, merancang, mengembangkan, dan menyebarluaskan dapat dilihat pada Gambar 1. Selain itu, tahap-tahap pengembangan 4D lebih sederhana dan sistematis. Sehingga dalam waktu pelaksanaan, pengembangan akan lebih mudah dan praktis (Solikin \& Amalia, 2019).

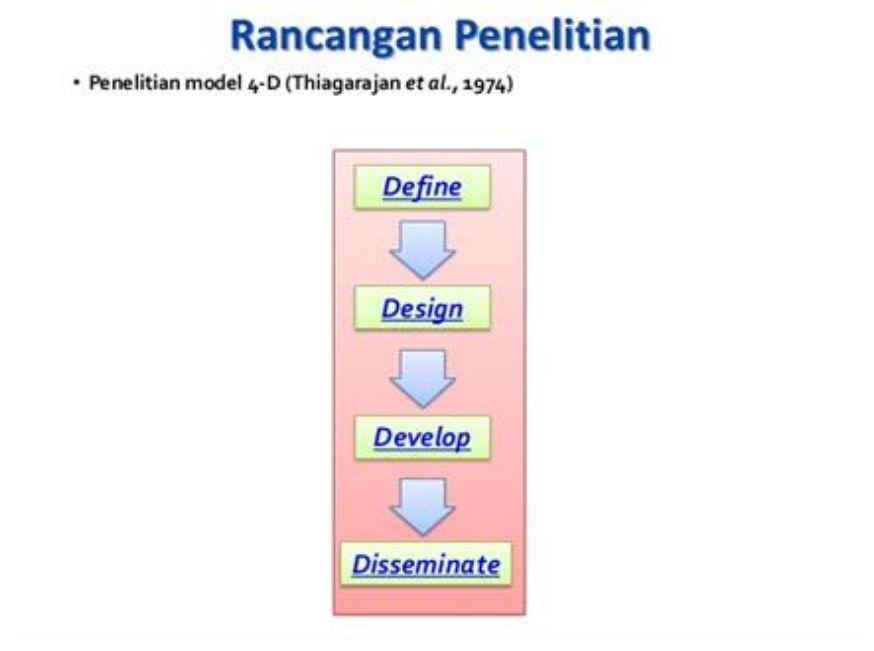

Gambar 1. Prosedur Pengembangan Model 4D

Tahap Pertama: Mendefinisikan

Define atau pendefinisian merupakan tahapan untuk menetapkan kebutuhan dan juga syarat untuk melakuakan pengembangan sebuah produk. Dalam pengembangan sebuah produk pasti dibutuhkan analisis kebutuhan yang tepat. Analisis pada tahap ini meliputi Secara umum, dalam pendefinisian ini dilakukan kegiatan analisis kebutuhan pengembangan, syarat-syarat pengembangan produk yang sesuai dengan 
kebutuhan pengguna serta model penelitian dan pengembangan (model R\&D) yang cocok digunakan untuk mengembangkan produk. Analisis bisa dilakukan melalui studi literatur atau penelitian pendahuluan. Dalam tahapan ini, terdapat 5 kegiatan yang dilakukan. Kegiatan tersebut yaitu:

\section{Analisis Awal}

Pengamatan yang telah dilakukan pada tahap ini menghasilkan beberapa permasalahan. Permasalahan utama yang ditemukan yaitu pada kegiatan belajar mengajar belum terdapat modul ajar yang dapat digunakan untuk proses belajar mandiri. Sehingga mahasiswa masih mengandalkan dan terpaku pada pemaparan materi yang diberikan oleh dosen. Oleh sebab itu mahasiswa sulit dalam memahami materi yang diberikan. Selanjutnya materi-materi yang diajarkan diadopsi untuk pembuatan modul mata kuliah Sosioteknologi Informatika dengan syarat telah memenuhi kurikulum yang berlaku.

\section{Analisis Peserta Didik}

Pembelajaran yang dilakukan pada Program Studi S1 teknik informatika khususnya pada mata kuliah Sosioteknologi Informatika masih terpaku pada pemaparan materi yang diberikan dosen. Penyampaian materi dengan media PPT masih membuat sebagian mahasiswa sulit mengerti dikarenakan materi yang kurang lengkap. Penggunaan gadget yang semakin berkembang juga membuat mahasiswa kurang berminat dengan bahan ajar cetak. Oleh sebab itu, modul dengan bentuk digital akan dipilih sebagai media yang akan dikembangkan.

\section{Analisis Konsep}

Kebutuhan untuk pembuatan modul akan di dasari dengan kurikulum Teknologi Informatika tahun 2018 katalog 2019 Program Studi S1 Teknik Informatika Fakultas Teknik Universitas Negeri Malang dengan 13 isi materi sebagai berikut: (1) konsep sosioteknologi informasi, (2) pengaruh teknologi terhadap dinamika social, (3) fungsi dan pelanggaran etika di dunia maya, (4) privacy dan kebebasan informasi, (5) kejahatan Internet, (6) metode mengamankan jaringan komunikasi data, (7) undang-undang hak cipta (8) lisensi perangkat lunak, (9) penerapan TI di bidang industry, (10) Penerapan TI di bidang pemerintahan, (11) penerapan TI di bidang Pendidikan (12) penerapan TI di bidang kesehatan, (13) kode etik profesi di bidang TI.

\section{Analisis Tugas}

Modul yang dibuat terdiri dari pendahuluan yang menjelaskan petunjuk penggunaan modul. Pada isi modul terdapat materi lengkap yang disusun secara sistematis untuk memudahkan mahasiswa dalam memahami. Modul juga deberikan evaluasi berbentuk link yang terhubung dengan studi kasus yang terbaru sehingga menambah referensi dan membantu memahami materi dengan jelas.

\section{Analisis Tujuan}

Tujuan dibuatnya modul dengan berdasarkan kurikulum yang berlaku dimaksudkan untuk mencapai indikator hasil belajar. Uraian tujuan pembelajaran pada modul mata kuliah Sosioteknologi Informatika pada Tabel 1.

Tabel 1 Tujuan Pembelajaran

\begin{tabular}{|c|c|}
\hline No & Tujuan Pembelajaran \\
\hline 1 & $\begin{array}{l}\text { Mahasiswa mampu memahami dan menyelesaikan contoh permasalahan pada materi konsep sosioteknologi } \\
\text { informasi }\end{array}$ \\
\hline 2 & $\begin{array}{l}\text { Mahasiswa mampu memahami dan menyelesaikan contoh permasalahan pada materi pengaruh teknologi terhadap } \\
\text { dinamika sosial }\end{array}$ \\
\hline 3 & $\begin{array}{l}\text { Mahasiswa mampu memahami dan menyelesaikan contoh permasalahan pada materi fungsi dan pelanggran etika di } \\
\text { dunia maya }\end{array}$ \\
\hline 4 & $\begin{array}{l}\text { Mahasiswa mampu memahami dan menyelesaikan contoh permasalahan pada materi pivasi dan kebebasan } \\
\text { informasi }\end{array}$ \\
\hline 5 & Mahasiswa mampu memahami dan menyelesaikan contoh permasalahan pada materi kejahatan internet \\
\hline 6 & $\begin{array}{l}\text { Mahasiswa mampu memahami dan menyelesaikan contoh permasalahan pada materi metode mengamankan } \\
\text { jaringan komunikasi data }\end{array}$ \\
\hline 7 & Mahasiswa mampu memahami dan menyelesaikan contoh permasalahan pada materi undang-undang dan hak cipta \\
\hline 8 & Mahasiswa mampu memahami dan menyelesaikan contoh permasalahan pada materi lisensi perangkat lunak \\
\hline
\end{tabular}




\begin{tabular}{cl}
\hline No & \multicolumn{1}{c}{ Tujuan Pembelajaran } \\
\hline 9 & $\begin{array}{l}\text { Mahasiswa mampu memahami dan menyelesaikan contoh permasalahan pada materi penerapan TI di bidang } \\
\text { industri }\end{array}$ \\
10 & $\begin{array}{l}\text { Mahasiswa mampu memahami dan menyelesaikan contoh permasalahan pada materi penerapan TI di bidang } \\
\text { pemerintahan }\end{array}$ \\
11 & $\begin{array}{l}\text { Mahasiswa mampu memahami dan menyelesaikan contoh permasalahan pada materi penerapan TI di bidang } \\
\text { Pendidikan } \\
12\end{array}$ \\
Mahasiswa mampu memahami dan menyelesaikan contoh permasalahan pada materi penerapan TI di bidang \\
kesehatan \\
Mahasiswa mampu memahami dan menyelesaikan contoh permasalahan pada materi kode etik profesi di bidang TI
\end{tabular}

Tahap Kedua: Desain

Tahap design ini adalah tahap dimana perancangan keseluruhan produk modul yang akan dibuat disiapkan landasannya. Tahap ini sangat penting dikarenakan pemilihan bahan ajar yang akan dibuat, peta konsep, isi hingga tahap revisi produk yang telah didesign dilakukan.

\section{Bahan Ajar yang dipilih}

Bahan ajar yang akan dipilih pada pengembangan produk ini berupa modul digital dikarenakan dapat digunakan sebagai bahan ajar mandiri dan juga bisa diakses melalui media gadget yang hampir semua mahasiswa mempunyainya. Penyusunan peta konsep mata kuliah didasarkan pada materi-materi yang akan dimuat pada modul dengan dasar kurikulum yang digunakan. Rancangan ini berisi 13 materi pokok yang akan dimuat di dalam modul.

\section{Pemilihan Format}

Format yang digunakan dalam modul mata kuliah Sosioteknologi Informatika akan dikembangkan dengan menggunakan jenis Times New Roman dengan ukuran 12 untuk memberikan kesan resmi dan mudah pembacaannya. Spasi pada ukuran kertas A4 yang akan digunakan ini diberi jarak antar baris 1,5 agar tidak terlalu rapat atau jauh sehingga teks tampak mudah dibaca. Selain itu penambahan tanda (ikon) akan mempermudah mengetahui hal penting yang terdapat pada isi dari materi. Penyusunan materi dibuat secara sistematis dan berurutan agar tidak membingungkan pengguna.

\section{Desain modul}

Pembuatan desain modul pembelajaran dilakukan setelah mendesain awal bentuk modul yang dikembangkan. Peneliti mendesain modul semenarik mungkin supaya peserta didik termotivasi membaca dan mempelajarinya sehingga terbentuk menjadi draft I

\section{Revisi Dosen Pembimbing}

Setelah rancangan telah dibuat pada tahap-tahap sebelumnya, kemudian hasil rancangan awal yang telah dibuat akan dikonsultasikan kepada dosen pembimbing. Selanjutnya modul akan dikembangkan sesuai saran dan revisi yang telah didapat.

\section{Tahap Ketiga: Pengembangan}

Pada tahap pengembangan ini untuk menghasilkan produk yang direvisi berdasarkan masukan para ahli. Tahap pengembangan ini mencakup tes validasi dan pengembangan oleh para ahli. Hasil validasi para ahli dan uji yang direvisi sampai produknya layak dan dapat digunakan untuk bahan ajar. Evaluasi dari para ahli dapat ditentukan oleh kriteria kelayakan yang diperoleh nilai rata-rata oleh responden. Selanjutnya nilai rata-rata responden dikonversi sesuai dengan tabel konversi untuk menentukan tingkat kelayakan modul pembelajaran berdasarkan responden.

Instrumen yang digunakan adalah angket yang diberikan berupa angket tertutup. Angket tertutup merupakan pertanyaan yang alternatif jawab-nya sudah ditentukan terlebih dahulu (Bachtiar, 2018). Pemilihan angket tertutup dipilih karena memiliki alternatif jawaban yang diberikan terstruktur dan sama antara satu dan yang lain. Jawaban yang diberikan responden mudah diproses karena alternatif jawaban telah terstruktur serta pertanyaan yang dikemukakan dalam kuesioner lebih jelas bagi responden karena dibantu oleh alternatif jawaban yang disediakan. Hal tersebut bertujuan untuk mempermudah pengembang dalam merevisi produk. Selain itu, data kualitatif dari masukan ahli untuk perbaikan bahan ajar modul juga 
dikumpulkan. Teknik analisis data dari nilai validitas bahan ajar modul adalah dengan cara mengonversi total skor yang ada pada instrumen validasi dengan kriteria validitas oleh (Sutrisno \& Akbar, 2018) yang ditunjukkan pada Tabel 2.

Tabel 2. Kriteria Validitas

\begin{tabular}{ccc}
\hline No & Tingkat Presentase & Tingkat Validitas \\
\hline 1 & $85,01 \%-100,00 \%$ & Sangat valid, atau dapat digunakan tanpa revisi. \\
2 & $70,01 \%-85,00 \%$ & Cukup Valid, atau dapat digunakan namun perlu revisi kecil. \\
3 & $50,01 \%-70,00 \%$ & Kurang valid, disarankan tidak dipergunakan karena perlu revisi besar. \\
4 & $01,00 \%-50,00 \%$ & Tidak valid, atau tidak boleh dipergunakan, perlu revisi besar-besaran. \\
\hline
\end{tabular}

Sedangkan data kualitatif yang didapat pada evaluasi oleh ahli merupakan masukan untuk perbaikan bahan ajar modul. Masukan tersebut berupa keterbatasan atau kekurangan yang akan digunakan sebagai acuan dalam merevisi produk bahan ajar modul yang dikembangkan.

\section{HASIL DAN PEMIBAHASAN}

Bahan ajar modul mata kuliah Sosioteknologi Informatika yang dikembangkan memiliki materi yang sesuai dengan kompetensi yang diajarkan pada mata kuliah Sosioteknologi Informatika di prodi S1 Teknik Informatika Universitas Negeri Malang. Dibuat sesuai dengan karakteristik peserta didik yaitu mahasiswa yang akan mengikuti mata kuliah Sosioteknologi Informatika di prodi S1 Teknik Informatika Universitas Negeri Malang. Urutan kegiatan pembelajarannya mengikuti model urutan kegiatan pembelajaran CDIO. Hasil pengembangan bahan ajar modul Sosioteknologi Informatika akan dipaparkan sebagai berikut.

\section{Halaman Sampul}

Sampul dengan judul Sosioteknologi Informatika yang dibuat dengan tulisan lebih besar dari tulisan lain yang ada bertujuan untuk membedakan antara judul utama yang akan digunakan dengan sub judul yang digunakan. Selain itu penulisan judul diletakkan ditengah agar terlihat jelas dan pengguna paham modul yang digunakan tentang apa. Sub judul dibuat dengan tujuan agar pengguna mengerti kalangan yang akan disasar pada modul yang dibuat. Untuk konsep nuansa warna biru yang digunakan menggambarkan warna yang biasa digunakan pada media-media sosial saat ini. Alasan konsep biru tersebut karena modul yang dibuat berhubungan dengan sosial. Terakhir penambahan identitas pembuat dirasa penting sehingga ditambahkan pada bawah cover yang dibuat.

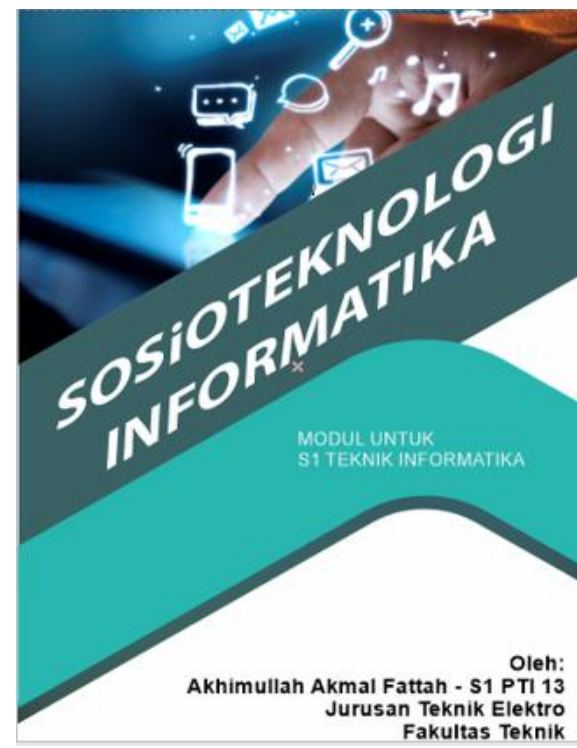

Gambar 2. Tampilan Halaman Sampul 


\section{Halaman Daftar Isi}

Di halaman daftar isi dimuat judul bab dan judul subbab yang disertai dengan nomor halaman tempat pembuatannya di dalam bahan ajar modul. Tampilan halaman daftar isi dapat dilihat pada Gambar 3.

\section{Pendahuluan}

Pada bagian pendahuluan diisi dengan empat bagian utama yaitu judul, tujuan, alokasi waktu dan petunjuk. Bagian pertama merupakan judul materi yang akan dibahas pada bab pembahasan. Pada bagian kedua merupakan tujuan yang ingin dicapai pada materi yang diberikan. Kemudian tidak lupa diberikan alokasi waktu untuk untuk memperjelas waktu yang akan diberikan untuk proses pembelajaran materi. Terakhir adalah petunjuk dalam mempelajari modul yang dibuat dengan menjelaskan apa yang harus dilakukan dari awal hingga akhir pembelajaran dan juga memberikan penjelasan mengenai simbol-simbol metode CDIO yang digunakan pada modul. Tampila pendahuluan dapat dilihat pada Gambar 4.

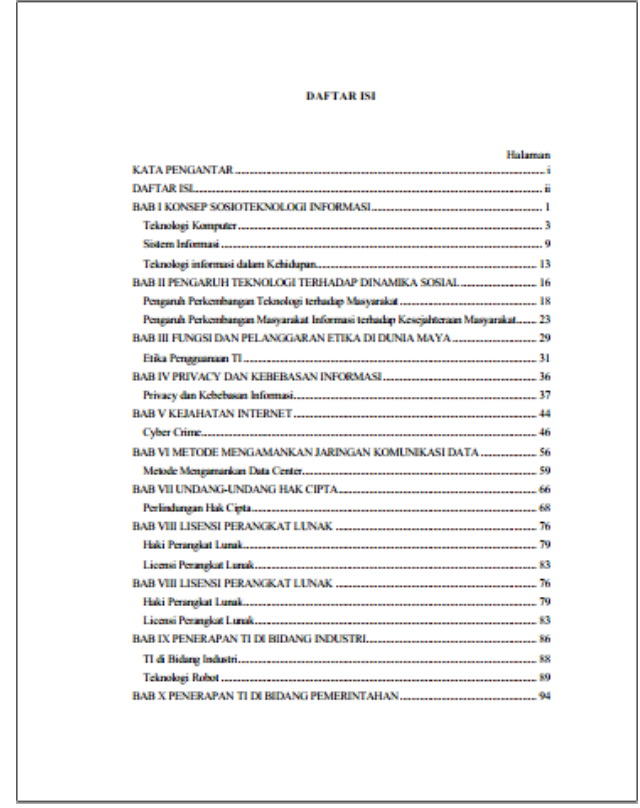

Gambar 3. Tampilan Daftar Isi

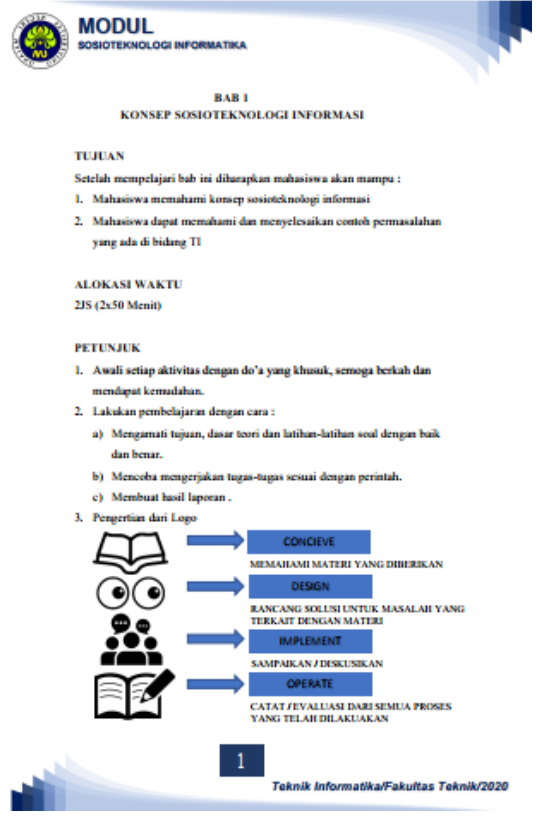

Gambar 4. Tampilan Pendahuluan

\section{Materi}

Bagian materi ini adalah awal metode CDIO yang digunakan pada modul (Zhulin, 2017). Simbol buku merupakan arti dari memahami yang merupakan langkah memahami sesuatu. Disini yang akan dipahami adalah materi yang diberikan. Materi yang disajikan akan dibuat secara lengkap dan tersusun sistematis sehingga memudahkan pengguna dalam memahami materi yang diberikan. Tampilan materi dapat dilihat pada Gambar 5.

\section{Urutan Kegiatan Pembelajaran Tahap Penutup}

Bagian evaluasi ini terdapat tiga bagian dari langkah metode CDIO yang digunakan yaitu langkah desain, implementasi, operasikan. Simbol mata merupakan arti dari langkah Design yang diberikan alamat atau sumber yang akan memperkuat memahami materi. Sumber disini diberikan alamat terupdate dari masalah-masalah yang ada pada kehidupan sosial. Sehingga wawasan tentang materi yang berhubungan dengan kehidupan sosial selalu ter-update. Simbol orang dengan tanda percakapan diatasnya memiliki arti diskusi yang merupakan langkah Implementasi dari metode CDIO (Bachtiar, 2018; Pham et al., 2014; Zhulin, 2017). Langkah ini merupakan pencarian solusi dari masalah yang telah diberikan pada langkah desain sebelumnya. Yang terakhir adalah simbol buku dengan pena yang mengartikan langkah pengoperasian dengan tujuan mengevaluasi hasil diskusi yang telah dilakukan dengan solusi dari anggota lain atau pendapat para ahli terkait solusi masalah tersebut. Tampilan tahap penutup dapat dilihat pada Gambar 6 . 

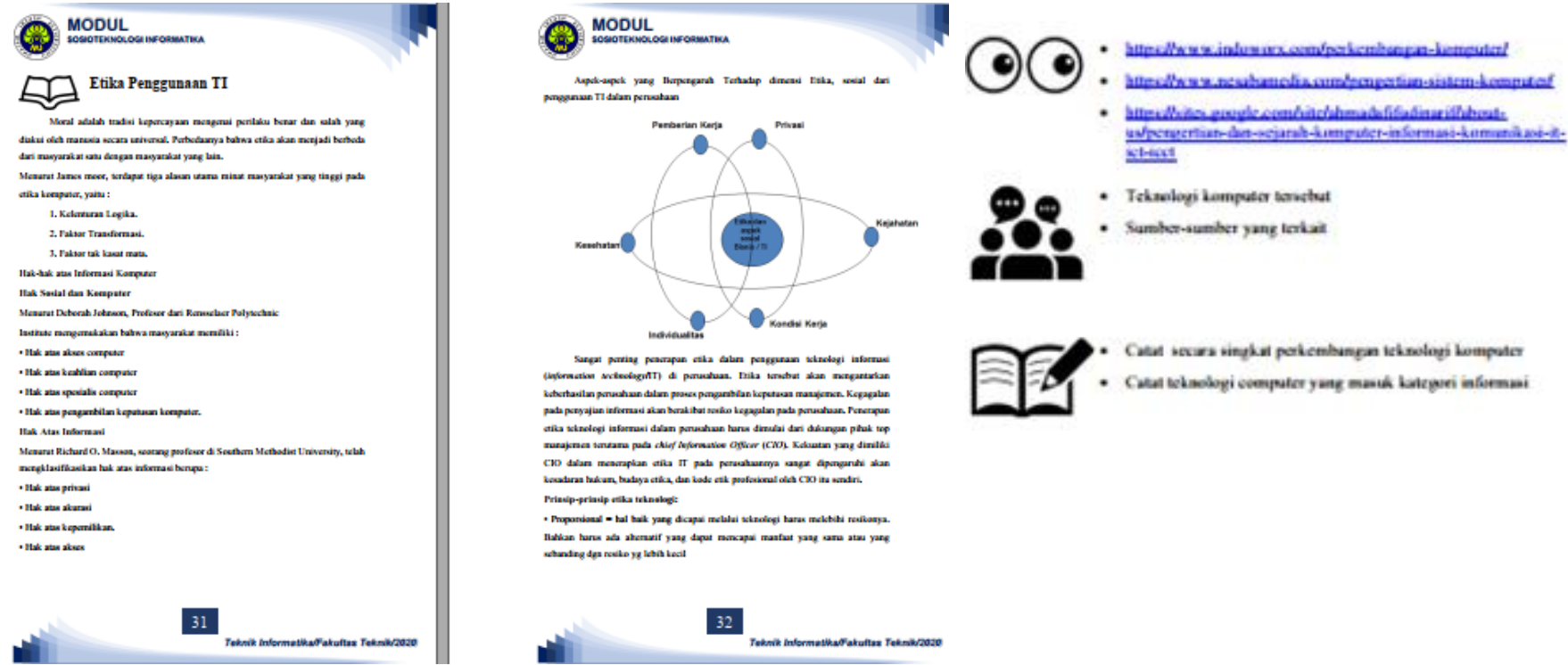

Gambar 5. Tampilan Materi

Gambar 6. Tampilan Evaluasi

\section{Halaman Daftar Pustaka}

Di halaman daftar pustaka dimuat daftar kumpulan sumber belajar yang dirujuk. Sumber belajar yang dirujuk adalah berbagai macam buku yang relevan dengan materi dan mengikuti perkembangan mutakhir. Karena menggunakan buku yang terbit dalam kurun waktu 10 tahun terakhir. Tampilan halaman daftar pustaka dapat dilihat pada Gambar 7.

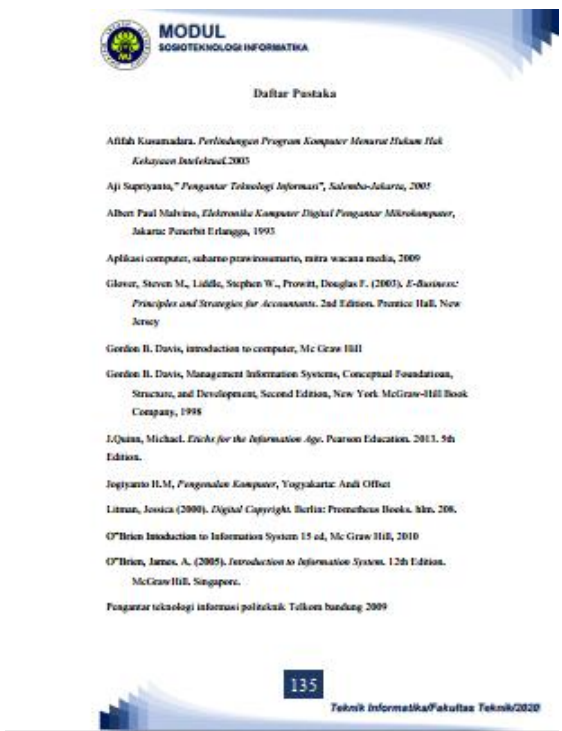

Gambar 7. Tampilan Halaman Daftar Pustaka

Hasil validiasi pengembangan bahan ajar modul mata kuliah Sosioteknologi Informatika yang diperoleh dari ahli pembelajaran mendapatkan skor $74,75 \%$, dan masuk kedalam kriteria cukup valid, atau dapat digunakan namun perlu revisi kecil. Hasil validasi bahan ajar modul yang dikembangkan dikatakan cukup valid karena sesuai dengan kriteria bahan ajar modul yang baik menurut (Daryanto, 2013; Sutrisno \& Akbar, 2018). 


\section{SIMIPULAN}

Produk yang telah dihasilkan dari pengembangan ini berupa modul digital. Modul ini digunakan sebagai penunjang proses pembelajaran pada mata kuliah Sosioteknologi Informatika bagi Program Studi S1 Teknik Informatika Jurusan Teknik Elektro Universitas Negeri Malang. Berdasarkan hasil hasil penelitian pengembangan yang telah dilakukan maka dapat ditarik kesimpulan bahwa modul yang dikembangkan berupa modul digital yang dapat digunakan sebagai penunjang proses pembelajaran mata kuliah Sosioteknologi Informatika bagi Program Studi S1 Teknik Informatika Jurusan Teknik Elektro Universitas Negeri Malang. Modul berisi 13 materi utama yang terdiri dari: (1) konsep sosioteknologi informasi, (2) pengaruh teknologi terhadap dinamika social, (3) fungsi dan pelanggaran etika di dunia maya, (4) privacy dan kebebasan informasi, (5) kejahatan Internet, (6) metode mengamankan jaringan komunikasi data, (7) undangundang hak cipta (8) lisensi perangkat lunak, (9) penerapan TI di bidang industri, (10) Penerapan TI di bidang pemerintahan, (11) penerapan TI di bidang Pendidikan (12) penerapan TI di bidang kesehatan, (13) kode etik profesi di bidang TI. Selain itu, di dalam modul juga disisipkan metode pembelajaran CDIO yang diimplementasikan ke dalam 4 tahap yaitu kegiatan concieve atau kegiatan pemahaman materi, Design atau kegiatan perancangan solusi permasalahan, implementation atau kegiatan diskusi untuk menentukan jawaban atau kegiatan mengevaluasi jawaban. Modul ini juga dapat dikembangkan menggunakan model 4-D atau model Thiagraja yang meliputi 4 tahap yaitu devine (perencanaan), design (perancangan), develop (pengembangan), dan desseminate (penyebaran). Modul Sosioteknologi Informatika yang dikembangkan dinilai cukup valid digunakan sebagai bahan ajar penunjang ditinjau dari presentase kevalidan dari ahli media sebesar $77 \%$ dengan kriteria cukup valid. Hasil presentase kevalidan dari ahli materi sebesar $72,5 \%$ dengan kriteria cukup valid. Dan hasil validitas gabungan adalah 74,75\% dengan kriteria cukup valid untuk digunakan dan dapat dilakukan sedikit revisi pada modul mahasiswa.

\section{DAFTAR RUJUKAN}

Anggoro, B. S. (2015). Pengembangan modul Matematika dengan strategi Problem Solvin guntuk mengukur tingkat kemampuan berpikir kreatif matematis siswa. Al-Jabar: Jurnal Pendidikan Matematika, 6(2), 121-130.

Anwar, I. (2010). Pengembangan bahan ajar. In Bahan Kuliah Online. Direktori UPI.

Bachtiar, Y. (2018). Penerapan konsep CDIO pada praktikum pemrograman komputer sebagai media pembelajaran kreatif dan aplikatif. Universitas Muhammadiyah Surakarta.

Cahyono, D. S. (2014). Pengembangan perangkat pembelajaran. Yogyakarta: Fokusindo Mandiri.

Daryanto, D. (2013). Menyusun modul bahan ajar untuk persiapan guru dalam mengajar. Yogyakarta: Gava Media.

Dwiyanto, F. A. (2018). Pengembangan bahan ajar berbasis CDIO untuk struktur data dengan bahasa Python di Jurusan Teknik Elektro Universitas Negeri Malang. In SKRIPSI Jurusan Teknik Elektro-Fakultas Teknik UM.

Harmawati, D., Indriwati, S. E., \& Gofur, A. (2017). Pengembangan modul berbasis inkuiri disertai multimedia interaktif pada siswa kelas VIII. Jurnal Pendidikan: Teori, Penelitian, Dan Pengembangan, 1(8), 1536-1539.

Lubis, M. S., Syahrul, R., \& Juita, N. (2014). Pengembangan modul pembelajaran bahasa indonesia berbantuan peta pikiran pada materi menulis makalah siswa kelas XI SMA/MA. Bahasa, Sastra, Dan Pembelajaran, 2(1), 16-28.

Nasrullah, R. (2018). Riset khalayak digital: Perspektif khalayak media dan realitas virtual di media sosial. Jurnal Sosioteknologi, 17(2), 271-287.

Pham, P. A., Nguyen, M. D., Nguyen, L. Q., Nguyen, T. M., \& Le, B. N. (2014). Learning computer programming in CDIO's team settings. Proc. 10th Annual Inter. CDIO Conf.

Prastowo, A. (2011). Panduan kreatif membuat bahan ajar inovatif. DIVA press.

Setyosari, P. (2010). Metode penelitian pendidikan dan pengembangan. Kencana.

Solikin, I., \& Amalia, R. (2019). Materi digital berbasis web mobile menggunakan Model 4D. SISTEMASI: Jurnal Sistem Informasi, 8(3), 321-328.

Sugiyono, S. (2016). Metodologi penelitian pendidikan: Pendekatan kuantitatif. Alfabeta.

Sutrisno, B., \& Akbar, I. (2018). E-partisipasi dalam pembangunan lokal (Studi implementasi smart city di Kota Bandung). Jurnal Sosioteknologi, 17(2), 191-207.

Utami, M. A., Lestari, M. T., \& Putri, B. P. S. (2016). Analisis strategi komunikasi pemasaran SMB Telkom University Tahun 2015/2016 melalui media sosial Instagram. EProceedings of Management, 3(1), 1-12.

Zhulin, L. I. (2017). A method for Data Structure Course Design Based on CDIO teaching idea 2. The Course Design Based on CDIO Model, 418-421. 